\title{
MUTATIONS MODULATE SOLUBLE CARBOHYDRATES COMPOSITION IN SEEDS OF LATHYRUS SATIVUS L.
}

\author{
AgNieszKa I. PIOTROWICZ-CIEŚLAK ${ }^{1}$, WoJCIECH RYBIŃSKI ${ }^{2}$, DARIUSZ J. MiCHALCZYK ${ }^{1}$ \\ ${ }^{1}$ Department of Plant Physiology and Biotechnology University of Warmia and Mazury \\ Oczapowskiego 1A, 10-718 Olsztyn, Poland \\ e-mail: acieslak@uwm.edu.pl \\ ${ }^{2}$ Institute of Plant Genetics, Polish Academy of Sciences \\ Strzeszyńska 34, 60-479 Poznań, Poland
}

(Received: April 24, 2007. Accepted: September 20, 2007)

\begin{abstract}
Seeds of Lathyrus sativus cv. Derek and Krab were used as biological material for induced mutagenesis. Three mutant lines were obtained from seeds of grass pea cv. Derek and 15 lines from mutagenised seeds of cv. Krab. Twelve ethanol-soluble carbohydrates were identified in the seeds. We have selected grass pea mutant lines with high oligosaccharides content (lines D4, K56, K25, and K7) and lines with low raffinose family oligosaccharides (RFO) content (lines K12, K29 and K13). Mutations changing the levels of RFO have not affected the contents of galactosyl cyclitols.
\end{abstract}

KEY WORDS: Lathyrus sativus L., seed, mutants, soluble carbohydrates, raffinose family oligosaccharides, galactosyl cyclitols.

\section{INTRODUCTION}

Lathyrus is a large genus within Leguminosae (= Fabaceae) family, subfamily Papilonoideae, tribe Vicieae, containing 187 species and subspecies that are found in both the Old World and the New World (Allkin et. al. 1983; Campbell 1997). One of these species (L. odoratus) is used as an ornamental plant and six species are cultivated as food or forage (L. cicera, L. clymenum, L. ochrus, L. tingita$n u s, L$. latifolius and $L$. sylvestris). Only grass pea (L. sativus) however, is fairly widely cultivated and used as food, feed and fodder crop (Jackson and Yunus 1984).

Lathyrus sativus is a pulse crop rich in protein, that can be easily grown on marginal land and under harsh environmental conditions and has great agronomic potential, especially in areas affected by drought (Lambein and Kuo 1997). Under adverse conditions grass pea is superior to other legume crops in yield, protein value, nitrogen fixation, and drought, flood and salinity tolerance. Lathyrus species have a considerable potential in crop rotation, improving soil physical conditions, limiting pathogen and weed populations, and thus reducing overall production costs (Vaz Patto et al. 2006). For these reasons grass pea is a major crop in Bangladesh, China, India and Pakistan and it is cultivated on a smaller scale in many countries of Europe, the Middle East, Northern Africa, as well as in Chile, Brazil and other countries of South America (Campbell et al. 1994). Grass pea was already in use in Neolithic times, and presently is considered a model crop for sustainable agriculture.

In Poland Lathyrus sativus is one of the least commonly produced grain legumes, grown mainly in Eastern Poland. It is used as a vegetable and is locally, incorrectly known as "soczewica Podlaska" (Podlaska lentil). The history of grass pea introduction to Poland is not clear. According to Milczak et al. (2001), it first appeared in Poland (in the region of Podlasie) as a weed accompanying lentil, as far back as 17th century, probably on arrival and settling down of the Tatars. Using old races (cultivated in Podlasie on small farms for family consumption) the first agricultural experiments were performed in the region of the free city of Gdańsk in 1932-1935. After the Second World War experiments were continued with Lathyrus sativus and $\mathrm{La}$ thyrus tingitanus. In 1992-1996 two most promising landraces of grass pea were selected, designated as 'Dr' and 'Kra' and released as new cultivars, added to the Register of Original Varieties in Poland.

Pulse crops, including grass pea, are a rich source of nutritive components. Protein is among the most significant of them, thank to its high content and the highest biological value of all plant sources. The protein content in grass pea is about 20-32\% (Grela and Günter 1995; Grela et al. $2001)$, that is higher than in field pea $(23 \%)$ or faba bean $(24 \%)$, although lower then in lupin - 32\% (Petterson et al. 1997) or soybean (42\%; Ravindran and Blair 1992). Because of its high protein level and easy growth, grass pea is 
the cheapest source of plant protein available in many countries. Grass pea proteins have a good content of essential amino acids, with only methionine insufficient (Lambein and Kuo 1997).

One of the major drawbacks of grass pea is the fact that the seeds contain anti-nutritional compounds, particularly $\beta$ - $N$-oxylamino-L-alanine (BOAA) (also known as $\beta-N$ -oxalyl-L- $\alpha, \beta$-diaminopropionic acid or ODAP). Following prolonged or excessive consumption of grass pea, the neurotoxin causes a drastic paralytic disease known as 'lathyrism' or 'neurolathyrism' (McCutchan 2003).

Carbohydrates, including starch and dietary fibre, vitamins of the B group and mineral compounds, are important nutritive components of grass pea (Lisiewska et al. 2003). The chemical composition of grass pea seeds is generally very similar to field pea and faba bean and is characterized by low fat and high starch content. Conversely, lupin has high fat and low starch content. The composition of the lipid fraction is generally similar to other grain legumes, with concentrations of stearic and linoleic acids in grass pea being a little higher and oleic acid slightly lower (Hanbury et al. 2000). Among soluble sugars, the main components are verbascose, stachyose and sucrose (Grela and Winiarska 1997; Troszyńska et al. 1993).

No doubt, genetic improvement is a prerequisite for broader utilization of this species. Induced mutagenesis, in addition to traditional recombination-based breeding may be used for this purpose (Waghmare and Mehra 2000; Rybiński 2003; Talukder and Biswas 2003; Talukder and Biswas 2005). The aim of the present paper was to compare soluble sugar contents in seeds of wild forms and mutants of grass pea obtained by laser irradiation and chemical mutagens.

\section{MATERIAL AND METHODS}

Seeds of two Polish cultivars of grass pea - 'Derek' and 'Krab' were used as biological material for induced mutagenesis. Seeds were irradiated for $30 \mathrm{~min}$ with a heliumneon laser light (wavelength $632 \mathrm{~nm}$ ) and subjected to two chemical mutagens - sodium azide $\left(\mathrm{NaN}_{3}\right)$ and N-nitroso$\mathrm{N}$-methylurea (MNU) as described in Rybiński 2003. Selection of mutants, morphologically different from the source material, was started in generation $\mathrm{M}_{2}$. In order to verify stability of changes observed in $\mathrm{M}_{2}$ generation, seeds of selected forms of this generation were sown, along with non-mutagenised (control) seeds of the same cultivars, and phenotypes of $\mathrm{M}_{3}$ generation were analysed. Stable morphological mutants of both cultivars were selected (17 mutants of the Krab cultivar and 3 mutants of the Derek cultivar) and used in field experiments set up according to the random block method with three replications. Seeds collected from those plants were used for analyses of soluble carbohydrates contents.

Cyclitols, galactosyl cyclitols and soluble sugars were analysed by GC chromatography according to the method of Piotrowicz-Cieślak (2005). Embryos (30-60 mg fresh mass) were homogenised in ethanol: water, 1:1 (v/v) containing $300 \mu \mathrm{g}$ phenyl- $\alpha$-D-glucose as internal standard. The homogenate and the rinse were combined in a $1.5-\mathrm{ml} \mathrm{mi-}$ crofuge tube, heated at $75^{\circ} \mathrm{C}$ for $30 \mathrm{~min}$ to inactivate endogenous enzymes and centrifuged at $15000 \mathrm{~g}$ for $20 \mathrm{~min}$. The supernatant was passed through a $10000 \mathrm{MW}$ cut-off filter (Lida, Kenosha, WI USA). Aliquots of $0.3 \mathrm{ml}$ filtrate were transferred to silylation vials and evaporated to dryness under a stream of nitrogen. Residues were kept overnight over phosphorus pentoxide in a desiccator. Dry residues were derived with $300 \mu$ of silylation mixture (trime-

TABLE 1. Carbohydrates composition in the seeds of Lathyrus sativus cv. Derek after induced mutagenesis [mg per g d.m. of seeds] (data are the means of 3-5 replications \pm standard deviation).

\begin{tabular}{|c|c|c|c|c|}
\hline Soluble carbohydrates & Derek & D4 & D11 & D13 \\
\hline Glucose & $0.85 \pm 0.25$ & $\operatorname{tr}$ & $0.78 \pm 0.07$ & $1.45 \pm 0.08$ \\
\hline Fructose & $0.29 \pm 0.01$ & $0.46 \pm 0.02$ & $0.67 \pm 0.06$ & $0.64 \pm 0.04$ \\
\hline Galactose & $\operatorname{tr}$ & $\operatorname{tr}$ & $\operatorname{tr}$ & $\operatorname{tr}$ \\
\hline Sucrose & $21.10 \pm 0.57$ & $95.91 \pm 5.67$ & $18.02 \pm 0.97$ & $17.61 \pm 1.58$ \\
\hline
\end{tabular}

Galactosyl cyclitols series ononitol

\begin{tabular}{llrr}
\hline Ononitol & $0.27 \pm 0.04$ & $0.24 \pm 0.04$ & $0.21 \pm 0.01$ \\
Galactoononitol & $0.47 \pm 0.03$ & $1.48 \pm 0.29$ & $0.66 \pm 0.03$
\end{tabular}

Galactosyl cyclitols series myo-inositol

\begin{tabular}{lccc}
\hline myo-inositol & $0.46 \pm 0.03$ & $2.36 \pm 0.08$ & $0.45 \pm 0.02$ \\
Galactinol & $1.47 \pm 0.04$ & $4.27 \pm 0.23$ & $1.14 \pm 0.13$ \\
Digalacto-myo-inositol & $0.92 \pm 0.08$ & $0.10 \pm 0.01$ & $0.09 \pm 0.01$ \\
\hline
\end{tabular}

Raffinose family oligosaccharides

\begin{tabular}{|c|c|c|c|c|}
\hline Raffinose & $2.74 \pm 0.06$ & $11.31 \pm 0.87$ & $2.70 \pm 0.08$ & $2.34 \pm 0.17$ \\
\hline Stachyose & $13.81 \pm 1.51$ & $46.22 \pm 2.34$ & $15.07 \pm 2.67$ & $25.19 \pm 1.67$ \\
\hline Verbascose & $5.74 \pm 1.09$ & $82.41 \pm 9.87$ & $9.21 \pm 0.97$ & $10.59 \pm 0.43$ \\
\hline Sum of RFO [mg/g] & 22.29 & 139.94 & 26.98 & 34.12 \\
\hline Sum of soluble sugars $[\mathrm{mg} / \mathrm{g}]$ & 48.11 & 244.74 & 49.00 & 61.02 \\
\hline Sucrose/RFO & 0.94 & 0.69 & 0.67 & 0.46 \\
\hline
\end{tabular}

$* \operatorname{tr}-$ trace 


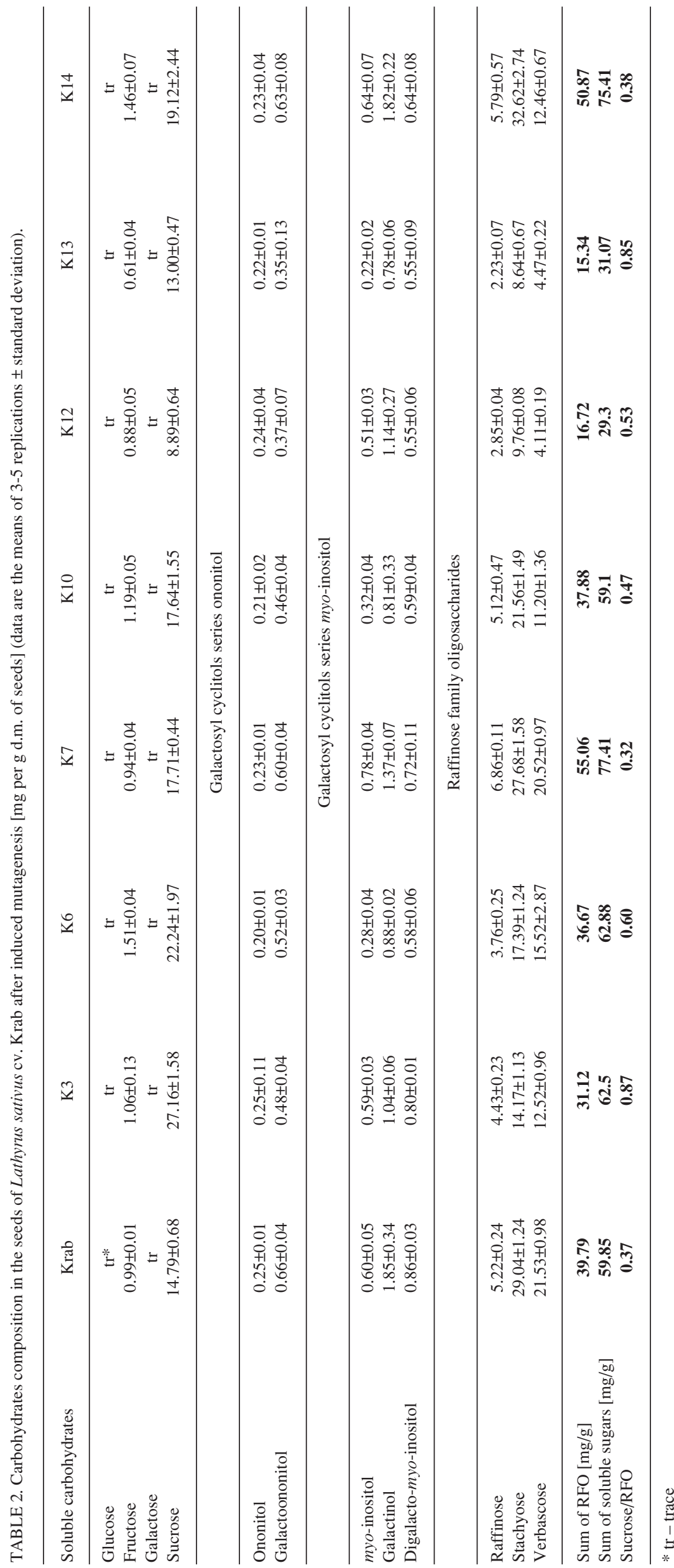

thylsilylimidazole: pyridine, $1: 1, \mathrm{v} / \mathrm{v}$ ) in silylation vials (Supelco) at $70^{\circ} \mathrm{C}$ for 30 min and then cooled at room temperature. One $\mu l$ carbohydrate extract was injected into a split-mode injector of a Shimadzu GC-14A gas chromatograph equipped with flame ionisation detector and Shimadzu C-R6A integrator. Soluble carbohydrates were analysed on a DB-1 capillary column (15 m length, $0.25 \mathrm{~mm}$ ID, 0.25 $\mu \mathrm{m}$ film thickness, J\&W Scientific). Soluble carbohydrates were identified with internal standards as available and calculated from the ratios of peak area for each analysed carbohydrate to the peak area of respective internal standard. Quantities of soluble carbohydrates were expressed as mean \pm SD for 3-5 replications of each treatment.

\section{RESULTS}

Three mutant lines were obtained from seeds of Lathyrus sativus L. cv. Derek and 15 lines from mutagenised seeds of cv. Krab and they were used, along with control (non-mutagenised) seeds, for analyses of soluble carbohydrates.

All seeds of Lathyrus sativus L. contained soluble carbohydrates including: monosaccharides (glucose, fructose, galactose), sucrose, raffinose family oligosaccharides (raffinose, stachyose, verbascose), cyclitols (myo-inositol, D-ononitol) and galactosyl cyclitols (galactinol, digalacto-myo-inositol, galactoononitol). Soluble carbohydrate content of cultivar Derek control (Table 1) seeds was 48.11 $\mathrm{mg} / \mathrm{g}$ dry mass (d.m.), while in Krab (Table 2) seeds it was $59.85 \mathrm{mg} / \mathrm{g} \mathrm{d.m}$. The average content of soluble carbohydrates in mutants of both cultivars was 56 $\mathrm{mg} / \mathrm{g}$ d.m. and $118 \mathrm{mg} / \mathrm{g}$ d.m., for Derek and Krab, respectively. However, separate lines differed in this respect quite significantly. Seeds of mutant line D11 of cultivar Derek had soluble carbohydrates level similar to non-mutagenised seeds, while in seeds of D4 line the level of these compounds was $245 \mathrm{mg} / \mathrm{g}$ d.m. (Table 1), so it increased five-fold compared to control. None of the Derek mutant lines had lower seed soluble carbohydrate level than control plants, whereas both lines with enhanced and depressed accumulation of seed soluble carbohydrates (SSC) were identified among Krab mutants. Lines K12 and K13 (Table 2) had the lowest SSC level, 29.3 and $31.1 \mathrm{mg} / \mathrm{g}$ d.m., respectively. Seeds of K7, K14 and K56 lines (Tables 2 and 2A) were characterised by the highest SSC - 77.4, 75.9 and 


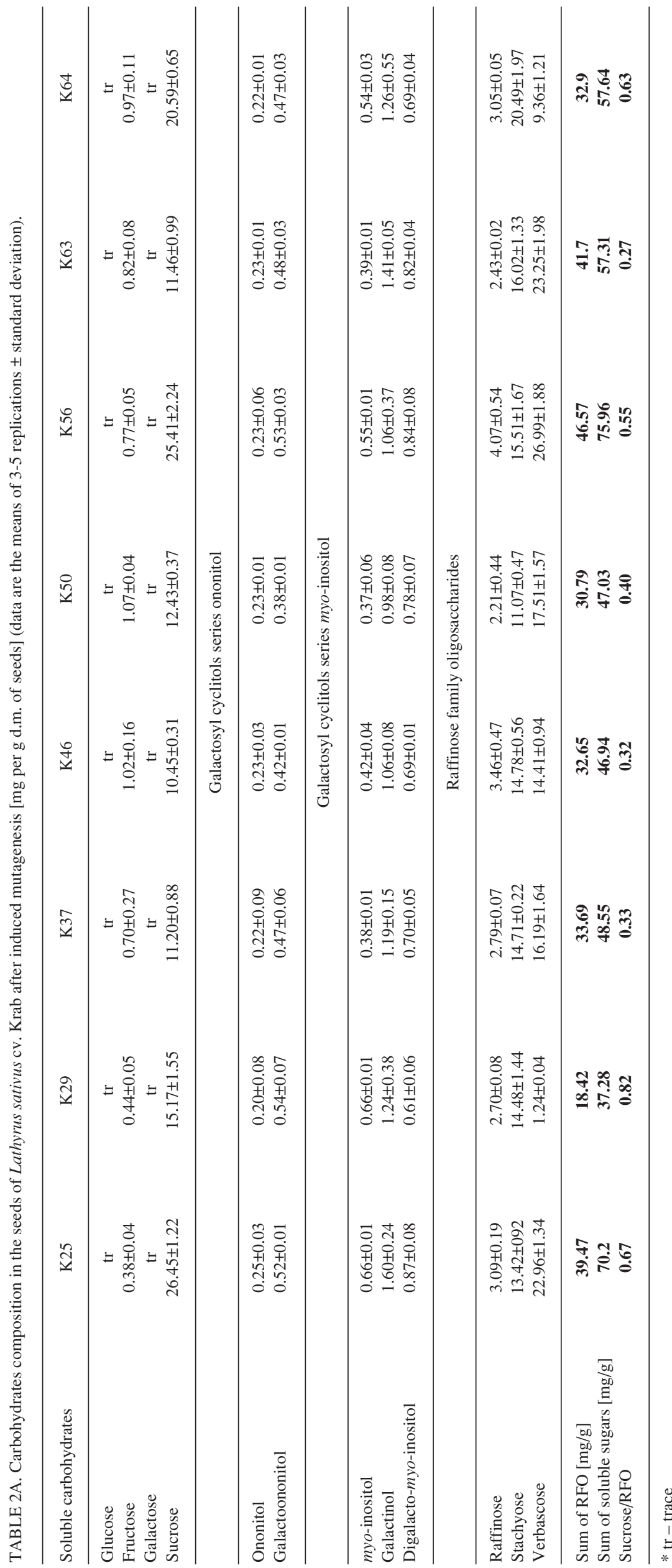

$75.4 \mathrm{mg} / \mathrm{g}$ d.m., respectively. Most of mutant lines (K6, K3, K63, K64, K10, $\mathrm{K} 46$, K37 and K50) however, produced seeds with unchanged amount of SSC.

Raffinose family oligosaccharides (RFO) were the main fraction of SSC and they made from $49 \%$ of soluble carbohydrates in line $\mathrm{K} 3$ to $73 \%$ in line K63 (Tables 2 and 2A). Among the RFO, raffinose occurred in the lowest amounts and it averaged $3.9 \mathrm{mg} / \mathrm{g} \mathrm{d.m}$. in all genotypes analysed. Line K 50 was characterised by the lowest $(2.21 \mathrm{mg} / \mathrm{g} \mathrm{d.m}$.) and line $\mathrm{K} 4$ by the highest raffinose level (11.3 $\mathrm{mg} / \mathrm{g}$ d.m.). The stachyose content was on average five-fold higher than the amount of raffinose. Similarly to raffinose, the level of stachyose varied significantly, and among Derek lines it was lowest in D11 (15.07 mg/g d.m.) and highest in D4 (46.2 mg/g d.m.) (Table 1). Among seeds of Krab mutants it was lowest in K12 and K13 (Table 2) - 9.76 and 8.64 $\mathrm{mg} / \mathrm{g} \mathrm{d.m}$. respectively, and it was highest in K14 (32.6 mg/g d.m.). Verbascose was the member of RFO, the amount of which showed the highest variation across the studied seeds - it ranged from 1.2 to $82.4 \mathrm{mg} / \mathrm{g}$ d.m. in $\mathrm{K} 29$ and D4 seeds (Tables 1 and 2A), respectively.

The galactosyl cyclitols of Lathyrus sativus seeds were derivatives of D-ononitol and myo-inositol. Galactoononitol, galactinol and digalacto-myo-inositol occurred in similar quantities (Tables 1, 2, and 2A) across all studied seeds, and averaged 0.54 , 1.39 and $0.61 \mathrm{mg} / \mathrm{g} \mathrm{d.m.,} \mathrm{respectively.}$

All seeds of Lathyrus sativus contained sucrose at fairly high levels, on average $21.7 \mathrm{mg} / \mathrm{g} \mathrm{d} . \mathrm{m}$. The highest level of sucrose occurred in seeds of D5 line (Table 1; $95.9 \mathrm{mg} / \mathrm{g} \mathrm{d.m.),} \mathrm{and} \mathrm{the} \mathrm{lowest} \mathrm{in} \mathrm{K12}$ line (Table 2; $8.89 \mathrm{mg} / \mathrm{g} \mathrm{d}$.m.).

A S/RFO ratio - sucrose/raffinose family oligosaccharides - was calculated for analysed seeds. Mutations decreased this index in seeds of cultivar Derek, most clearly in line D13. S/RFO index was low $(0.37)$ in cultivar Krab, even in control seeds, and it was still diminished in mutant lines K63, K7, K46, K37. On the other hand, in seeds of lines K29, K3 and K13 it was twice as high as in non-mutagenised control (Tables 1, 2, and 2A).

\section{DISCUSSION}

Seed carbohydrate composition has already been studied in a number of legumes, including lentil (Frias et al. 1999), pea (Kvasnička et al. 1994), soybean (Lowell and Kuo 1989) and lupin (Piotro- 
wicz-Cieślak et al. 2005). Raffinose family oligosaccharides (RFO) are the main storage material in legume seeds reaching the level of a few per cent (pea, bean) to several per cent of dry mass (lupin; Cerning-Beroard, Filiatre 1976). The RFO level varies depending on species, variety, temperature of maturation, maturity level, storage regime (Piotrowicz-Cieślak 2006; Philips and Abbey 1989; Revilleza et al. 1990). The analysed seeds of grass pea mutants accumulated soluble carbohydrates to $2.9-24.5 \%$ d.m. (Tables 1, 2 and 2A). The fraction of RFO in total seed carbohydrates was 49.4 to $72.7 \%$.

The analysed mutant lines can be divided into two categories: 1) those with increased oligosaccharide contents and 2) with lowered amounts of these compounds. The increase in RFO level might be favourable for practical/nutritional use of legume seeds, although the estimations of dietary role of these compounds vary widely. Price et al. (1988) believe that the presence of $\alpha-(1 \rightarrow 6)$-galactosyl bonds in RFO render these compounds antinutritious agents. In the digestive tract of humans and monogastric animals the enzymes decomposing $\alpha$ - $(1 \rightarrow 6)$-galactosyl bonds are lacking, so RFO are not hydrolysed until they get to the thick intestine and surrender to the bacterial galactosidase. The discomfort felt after ingestion of RFO is caused by intestinal Enterobacteriacae, as they release hydrogen, methane and carbon dioxide. However, it was shown by Thomomatsu (1994) that regular ingestion of larger quantities of RFO stimulates other components of the bacterial flora of the gut. In humans and animals consuming RFO, the chief components of the microflora are bifidobacteria. The dominance of these bacteria results from the presence of "bifidogenic agent" in food. The main product of bidfidobacteria fermentation is acetic acid, which lowers the $\mathrm{pH}$ of intestinal contents and exerts a strong bacteriostatic action against pathogenic strains. Moreover, bifidobacteria act favourably on their human hosts by stimulating the immune system and producing antimicriobial substances (so called. bacteriocines), inhibiting the growth of pathogenic strains (Stolarczyk 2001). Consumption of $\alpha$-galactosides decreases the incidence of thick intestine cancers (Hozyasz 2002). Considering the above data some researchers do not consider RFO as antinutritive compounds. On the contrary, suggestions of enrichment human or animal diet in RFO are put forward.

No doubt RFO have important physiological roles to fulfil in plants. They are a transport form of sugars in many plants (Haritatos et al. 2000). They accumulate in plants in response to environmental stresses, i.e. high or low temperature, dehydration (Ashworth et al. 1993; Bachmann et al. 1994; Taji et al. 2002; Piotrowicz-Cieślak 2006). RFO participate in the process of plant tissue adaptation to desiccation in orthodox seeds (Górecki et al. 1997). They can alleviate the state of plants challenged with biotic or abiotic stresses (Lin and Huang 1994; Steadman et al. 1996).

According to Koster and Leopold 1988; Leprince et al. 1993; Black et al. 1996; Brenac et al. 1997, RFO are being accumulated in maturing seeds of many species, and there is a positive correlation between the level of these compounds and seed longevity (Bernal-Lugo and Leopold 1992; Bernal-Lugo and Leopold 1995). The ratio of seed sucrose/raffinose family oligosaccharides (S/RFO) seems particularly relevant. According to Xiao and Koster (2001) a proper ratio of sucrose to RFO (85:15) efficiently pro- tects embryos of pea (Pisum sativum) from lethal protoplast dehydration. The S/RFO mass ratio may be used as an index of seed storability. Seeds described in this report were characterised by S/RFO ratio below 1 , which may be indicative of their good storability. The biosynthesis of RFO uses up monosaccharides - glucose, fructose and galactose - and thus it may significantly reduce the level of reducing sugars in seeds (Leprince et al. 1993). As a consequence it may limit Maillard's reactions, responsible for protein deterioration (Wettlaufer and Leopold 1991). In these reactions reducing sugars condense with amino acids, pepetides or proteins and form Schiff bases which undergo further modifications to dark coloured polymerisation products. RFO can serve as free radical scavengers, and this role may be of special significance in sensitive tissues subjected to dehydration (Vertucci and Farrant 1995). According to Downie and Bewley 2000 RFO may be the main, readily metabolised source of metabolic energy in germinating seeds.

Galactosyl cyclitols are a big group of metabolites occurring in many plant species (Horbowicz and Obendorf 1994). Seeds of buckwheat and castor bean are particularly rich in galactosyl cyclitols. Among legumes, Lupinus pilosus and Lupinus palaestinus seeds accumulate appreciable amounts of galactosyl cyclitols (Michalczyk et al. 2006). Galactosyl cyclitols, as is shown in this report, also occur in seeds of Lathyrus sativus L. They are derivatives of myo-inositol and D-ononitol (Tables 1,2 and 2a) and occur in rather low amounts in both control (non-mutated) and mutant lines derived from cultivars Derek and Krab.

Mutants with increased contents of soluble carbohydrates (compared to wild type plants) were characterised by decreased all seed number, seed mass and plant size (conf. Rybiński and Starzycki, 2004). On the other hand, mutants of grass pea with low RFO levels grew into bigger plants, produced more seeds and had higher seed mass. Considering a strong propensity of grass pea for lodging (Rybiński and Pokora 2002), the smaller size of grass pea plants may be considered a desirable trait. The same holds true for high content of RFO-compounds with potential health promoting activity. On the other hand, small seed mass and low seed number must be regarded as unfavourable features. However, comparing different mutants we can conclude that the above traits are not linked very closely and it is possible to select forms like D13, K3 and K64 which are characterised by both increased RFO content, good seed production (conf. Results) and small plant size (Rybiński and Starzycki 2004).

Published data show that within Lathyrus genus there is a considerable natural variation of sucrose and its $\alpha$-galactosides contents - in seeds of Lathyrus maritimus sucrose, stachyose, and verbascose occur at the level of $0.67 \%$; $1.37 \%$; and $0.73 \%$, respectively; in the Indian grass pea (Lathyrus sativus) at $0.30,0.78$ and $0.52 \%$, respectively and in seeds of Canadian grass pea (Lathyrus sativus) at 0.67, 0.86 and $0.48 \%$, respectively (Chavan et al. 2003). Among the mutants used in this study (Tables 1, 2, and 2A), all belonging to the same species $-L$. sativus - even a wider variation of sucrose and RFO was noted - both forms with increased and decreased levels of these compounds have been found (sucrose, stachyose and verbascose in mutants ranged from $0.88-9.59 \%, 0.86-4.6 \%, 0.4-8.2 \%$, respectively). However, all mutants accumulated galactosyl 
cyclitols at similar levels, close to those found in the nonmutated L. sativus seeds (the range of natural variation of galactosyl cyclitols contents across other Lathyrus species is not known). It seems therefore, that the levels of both classes of seed soluble carbohydrates - galactosyl cyclitols and RFO - are controlled by different sets of genes.

\section{LITERATURE CITED}

ALLKIN R., MACFARLANE T.D., WHITE R.J., BISBY F.A., ADEY M. 1983. Names and synonymus of species and subspecies in the Vicieae. Issue 2, Vicieae database project publication, Southampton, UK, No. 2.

ASHWORTH E.N., MALONE S.R., RISTIC Z. 1993. Response of woody plant cells to dehydrative stress. Int. J. Plant Sci. 154: 90-99.

BACHMANN M., MATILE P., KELLER F. 1994. Metabolism of the raffinose family oligosaccharides in leaves of Ajuga reptans L. Cold acclimation, translocation, sink to source transition: discovery of chain elongation enzyme. Plant Physiol., 105: 1335-1345.

BERNAL-LUGO I., LEOPOLD A.C. 1995. Seed stability during storage: raffinose content and glassy state. Seed Sci. Res. 5: 75-80.

BERNAL-LUGO I., LEOPOLD A.C. 1992. Changes in soluble carbohydrates during seed storage. Plant Physiol., 98: 1207-1210.

BLACK M., CORBINEAU F., GRZESIK M., GUY P., COME D. 1996. Carbohydrate metabolism in the developing and maturing wheat embryo in relation to its desiccation tolerance. J. Exp. Bot., 47: 161-169.

BRENAC P., SMITH M.E., OBENDORF R.L. 1997. Raffinose accumulation in maize embryos in the absence of a fully functional Vp1 gene product. Planta, 203: 222-228.

CAMPBELL C.G. 1997. Grass pea - Lathyrus sativus L. IPGRI. Promoting the Conservation and Use of Underutilized and Neglected Crops 18: 1-92.

CAMPBELL C.G., MEHRA R.B., AGRAWAL S.K., CHEN Y.Z., MONEIM A.M., KHAWAJA H.I.T., YADOW C.R., TAY J.U., ARAYA W.A. 1994. Current status and future strategy in breeding grasspea. Euphytica 73: 167-175.

CERNING-BEROARD J., FILIATRE A. 1976. A comparison of the carbohydrate composition of legume seeds: hoorsebeans, peas, and lupines. Cereal Chem., 53: 968-978.

CHAVAN U.D., MCKENZIE D.B., AMAROWICZ R., SHAHIDI F. 2003. Phytochemical components of beach pea (Lathyrus maritimus L.). Food Chem., 81: 61-71.

DOWNIE B., BEWLEY J.D. 2000. Soluble content sugar of white spruce (Picea glauca [Moench Voss)] seeds during and after germination. Physiol. Plant. 110: 1-12.

FRIAS J., BAKHSH A., JONES D., ARTHUR A., VIDAL-VALVERDE C., RHODES M., HEDLEY C. 1999. Genetic analysis of the raffinose oligosaccharide pathway in lentil seeds $\mathrm{J}$. Exp. Bot., Vol. 50: 469-476.

GÓRECKI, R.J., PIOTROWICZ-CIEŚLAK A.I., OBENDORF R.L. 1997. Soluble sugars and flatulence-producing oligosaccharides in maturing yellow lupin (Lupinus luteus L.) seeds. Seed Sci. Res., 7: 185-193.

GRELA E.R., GÜNTER K.D. 1995. Fatty acid composition and tocopherol content of some legume seeds. An. Feed Sci. Technol. 52: 325-331.

GRELA E.R., STUDZIŃSKI T., MATRAS J. 2001. Antinutritional factors in seed of Lathyrus sativus cultivated in Poland. Lathyrus Lathyrism Newsletter 2 (2): 101-104.

GRELA E.R., WINIARSKA A. 1997. Chemical composition and nutritive value of flat pea (Lathyrus sativus L.) seeds. Lathyrus sativus - cultivation and nutritive value in animal and humans. Int. Conf., Poland, Radom, 9-10 June 1997, 49-55.
HANBURY C.D., WHITE C.L., MULLAN B.P., SIDDIQUE K.H.M., 2000. A review of the potential of Lathyrus sativus L. and L. Cicera, L. grain for use as animal feed. Anim. Feed Sci. Technol. 87: 1-27.

HARITATOS E., MEDVILLE R., TURGEON R. 2000. Minor vein structure and sugar transport in Arabidopsis thaliana. Planta, 211: 105-111.

HORBOWICZ M., OBENDORF R.L. 1994. Seed desiccation tolerance and storability: dependence on flatulence-producing oligosaccharides and cyclitols - review and survey. Seed Sci. Res., 4: 385-405.

HOZYASZ K. 2002. Probiotyki i prebiotyki - nowe propozycje w żywieniu niemowląt. Medycyna Rodzinna, 17 (1). (in Polish)

JACKSON M.T., YUNUS A.G. 1984. Variation in the grass pea (Lathyrus sativus L.) and wild species. Euphytica 33: 549-559.

KOSTER K.L, LEOPOLD A.C. 1988. Sugars and desiccation tolerance in seeds. Plant Physiol., 88: 829-832.

KVASNIČKA F., AHMADOVÁ-VAVROUSOVÁ R., MRSKOŠ M., VELÍŠEK J., KADLEC P. 1994. Characteristics of pea varieties according to galactooligosaccharides content. Agrifood quality: An interdisciplinary approach: 153-156.

LAMBEIN F., KUO Y.H. 1997. Lathyrus sativus, a neolithic crop with a modern future? An overview of the presnt situation. Lathyrus sativus - cultivation and nutritive value in animal and humans. Int. Conf., Poland, Radom, 9-10 June 1997, 6-12.

LEPRINCE O., HENDRY G.A.F., MCKERSIE B.D. 1993. The mechanisms of desiccation tolerance in developing seeds. Seed Sci. Res., 85: 581-588.

LIN T.P., HUANG N.H. 1994. The relationship between carbohydrate composition of some tree seeds and their longevity. J. Exp. Bot., 45: 1289-1294.

LISIEWSKA Z., KORUS A., KMIECIK W. 2003. Changes in chemical composition during development of grass pea ( $L a$ thyrus sativus L.) seeds. Nahrung/Food 47 (6): 391-396.

LOWELL, C.A., KUO, T.M. 1989. Oligosaccharides metabolism and accumulation in developing soybean seeds. Crop Sci. 29: 459-465,

McCUTCHAN J.S. 2003. Rewiev: A brief history of grasspea and its use in crop improvement. Lathyrus Lathyrism Newsletter 3: 18-23.

MICHALCZYK D.J, PIOTROWICZ-CIEŚLAK A.I., SAWICKA-SIENKIEWICZ E., GALEK R., BOCHENEK A., GŁOWACKA K. 2006. Diversity of seed coat ultrastructure and soluble carbohydrates contents in Lupinus atlanticus, L. cosentinii and L. pilosus. Acta Biologia Cracoviensia Serias Botanica 48/1: 59-68.

MILCZAK M., PĘDZIŃSKI M., MNICHOWSKA H., SZWEDURBAŚ K., RYBIŃSKI W. 2001. Creative breeding of grasspea (Lathyrus sativus L.) in Poland. Lathyrus Lathyrism Newsletter 2: 101-104.

PETTERSON D.S., SIPSAS S., MACKINTOSCH J.B. 1997. The chemical composition and nutritive value of Australian pulses. Grains Research and Development Corporation, Canberra 42$-49$.

PHILLIPS M.C., ABBEY B.W. 1989. Composition and flatulence-producing potential of commonly eaten Nigerian and American legumes. Food Chem., 33: 271-280.

PIOTROWICZ-CIEŚLAK A.I. 2005. Changes in soluble carbohydrates in yellow lupin seed under prolonged storage. Seed Sci. Tech., 33: 141-145

PIOTROWICZ-CIEŚLAK A.I. 2006. Effects of temperature on the soluble carbohydrates accumulation of maturing yellow lupin seeds. Acta Physiol. Plant., 28 (4) 349-356.

PRICE K.R., LEWIS J., WYATT G.M., FENWICK G.R. 1988. Flatulence-Causes, relation to diet and remedies. Nahrung 32: 609-623. 
RAVINDRAN V., BLAIR R. 1992. Feed resources for poultry production in Asia and the Pacific. II. Plant Protein Sources. World Poult. Sci. J. 48: 205-231.

REVILLEZA M.J.R., MENDOZA E.M., RAYMUNDO L.C. 1990. Oligosaccharides in several Philippine indigenous food legumes: determination, localization and removal. Plant Foods Hum. Nutr. 40: 83-93.

RYBIŃSKI W. 2003. Mutagenesis as a tool for improvement of traits in grasspea (Lathyrus sativus L.). Lathyrus Lathyrism Newsletter 3: 27-31.

RYBIŃSKI W., POKORA L. 2002. Wpływ światła lasera helowo-neonowego i chemomutagenu (MNU) na zmienność cech lędźwianu siewnego (Lathyrus sativus L.). Acta Agrophysica 62: 127-134. (in Polish)

RYBINSSKI W., STARZYCKI M. 2004. Ocena zmienności genetycznej cech mutantów lędźwianu siewnego (Lathyrus sativus L.). Zeszyty Problemowe Postępów Nauk Rolniczych 497: 539-550. (in Polish)

STEADMAN KJ, PRITCHARD HW, DEY PM. 1996. Tissuespecific soluble sugars as indicators of storage category. Ann. Bot. 77: 667-674.

STOLARCZYK A. 2001. Rola oligosacharydów w żywieniu niemowląt. Nowa Pediatria - zeszyt 27. (in Polish)

TAJI T., OHSUMI C., LUCHI S., SEKI M., KASUGA M., KOBAYASHI M., YAMAGUCHI- SHINOZAKI K., SHINOZAKI K. 2002. Important roles of drought- and cold-inducible genes for galactinol synthase in stress tolerance in Arabidopsis thaliana. Plant J., 29: 417-426
TALUKDER D., BISWAS A.K. 2003. Characterisation of an induced mutants and its inheritance in grasspea (Lathyrus sativus L.). Indian J. Genet. Plant Breed. 62 (4): 355-256.

TALUKDER D., BISWAS A.K. 2005. Induced seed colour mutations and their inheritance in grasspea (Lathyrus sativus L.). Indian J. Genet. Plant Breed. 65 (2): 135-136.

THOMOMATSU H. 1994. Health effects of oligosaccharides. Food Technol., 48: 61-65.

TROSZYŃSKA A., HONKE J., MILCZAK M., KOZŁOWSKA H., 1993. Antinutritional substances in lentil (Lens culinaris) and everlasting pea (Lathyrus sativus). Pol. J. Food Nutr. Sci., 2: 49-54.

VAZ PATTO M.C., SKIBA B., PANG E.C.K., OCHATT S.J., LAMBEIN F., RUBIALES D. 2006. Lathyrus improvement for resistance against biotic and abiotic stresses: From classical breeding to marker assisted selection. Euphytica 147: 133-147.

VERTUCCI C.W., FARRANT J.M. 1995. Acquisition and loss of desiccation tolerance. In Kigel J and Galili G (eds). Seed Development and Germination (Marcel Dekker, New York) 237-271.

WAGHMARE V.N., MEHRA R.B. 2000. Induced mutation in grasspea (Lathyrus sativus L.). Lathyrus Lathyrism Newsletter 1: $21-24$

WETTLAUFER S.H., LEOPOLD A.C. 1991. Relevance of Amador and Maillard products to seed deterioration. Plant Physiol., 97: 165-169.

XIAO L., KOSTER K.L. 2001. Desiccation tolerance of protoplasts isolated from pea embryos. J. Exp. Bot., 364: 2105-2114. 